\title{
An assessment of population fluctuations of citrus pest woolly whitefly Aleurothrixus floccosus (Maskell, 1896) (Homoptera, Aleyrodidae) and its parasitoid Cales noacki Howard, 1907 (Hymenoptera, Aphelinidae): A case study from Northwestern Algeria
}

\author{
Abdelhaq MAHMOUDI ${ }^{1}$, Leila ALLAL BENFEKIH ${ }^{1}$, Abdurrahman YIGIT $^{2}$, Mattheus F. A. GOOSEN ${ }^{3}$
}

Received March 19, 2018; accepted June 19, 2018.

Delo je prispelo 19. March 2018, sprejeto 19. junija 2018.

\begin{abstract}
The aim of this study was to assess the effectiveness of the parasitoid Cales noacki Howard, 1907 (Hymenoptera, Aphelinidae) in the biological control of the citrus pest woolly whitefly, Aleurothrixus floccosus (Maskell,1896) in Northwestern Algeria. In particular the pest and parasitoid population fluctuations under different environmental conditions were investigated. The study was conducted by examination and sampling of whitefly adult populations on young shoots and catches as well as its parasitoid during a 12month period by counting the parasite and infested-live larvae. Results showed remarkable variations in abundance indices and infestation rates of larvae and adults that depended on the growth flush in foliage and meteorological conditions of the region. The woolly whitefly manifested three flight periods coinciding with three growth flushes of orange sap; in autumn towards the end of September followed by mid-November with the highest average abundance of 10 individuals per branch and a third flight period in mid-May. Phases of growth flush seemed to have an effect on the temporal distribution of adults over the sampling period from July to June. Pest emergence appeared favorable at $12-20{ }^{\circ} \mathrm{C}$ as the minimum interval temperature whereas the maximum varied between $25-33{ }^{\circ} \mathrm{C}$ with humidity levels of $50 \%$ and $75 \%$. As for the incidence of natural enemies on whiteflies, despite their abundance, their impact was not optimum due to the large fluctuations in number of whiteflies. Although the pestparasitoid complex appears to be important in the orchard, the biological regulation exerted by $C$. noacki while effective is insufficient for the complete neutralization of citrus woolly whitefly A. floccosus. An integrated approach is needed using additional natural enemies associated with the woolly whitefly.
\end{abstract}

Key words: citrus; biological control; population dynamics; Aleurothrixus floccosus; Cales noacki; phenology; Chlef Northwestern Algeria
IZVLEČEK

\author{
OVREDNOTENJE NIHANJA POPULACIJ \\ ŠKODLJIVCA CITRUSOV, ŠČITKARJA Aleurothrixus \\ floccosus (Maskell, 1896), IN NJEGOVEGA \\ PARAZITOIDA Cales noacki Howard, 1907: VZORČNA \\ ŠTUDIJA IZ SEVEROZAHODNE ALŽIRIJE
}

Namen raziskave je bil oceniti učinkovitost parazitoida Cales noacki Howard, 1907 (Hymenoptera, Aphelinidae) pri biotičnem zatiranju škodljivca citrusov, ščitkarja Aleurothrixus floccosus (Maskell, 1896), v severozohaodni Alžiriji. Še posebej je bilo preučevano nihanje populacij škodljivca in parazitoida $\mathrm{v}$ odvisnosti od različnih okoljskih razmer. $\mathrm{V}$ raziskavi so bile pregledane in vzorčene populacije odraslih osebkov ščitkarja na mladih poganjkih in v pasteh ter njihovi parazitoidi v obdobju 12mesecev s štetjem parazitoida in napadenih, a živih ličink. Rezultati so pokazali znatne razlike $\mathrm{v}$ indeksih pogostosti in napadenosti ličink in odraslih, kar je bilo odvisno od dinamike rasti listov in meteoroloških razmer območja. Preučevani ščitkar je imel tri rodove, ki so sovpadali s tremi viški rasti in pretoka sokov pomarančevca in sicer konec septembra, $\mathrm{v}$ sredini novembra $\mathrm{z}$ največjim številom 10 osebkov na vejico, in tretji, $v$ sredini maja. Obdobja rasti pomarančevca so vplivala na časovno pojavljanje odraslih osebkov $\mathrm{v}$ obdobju od julija do junija. Najnižji ustrezen temperaturni interval za pojav škodljivca je bil med 12 in $20^{\circ} \mathrm{C}$, najvišji pa med 25 in $33^{\circ} \mathrm{C}$ pri relativni vlagi 50 in $75 \%$. Pojav naravnih sovražnikov ščitkarja kljub njegovi številčnosti ni bil optimalen zaradi velikega nihanja populacije škodljivca. Čeprav je kompleks škodljivca in parazitoida pomemben v sadovnjaku, je biotično uravnavanje s parazitoidom C. noacki nezadostno za celovito nevtralizacijo ščitkarja na citrusih. Zato je potreben integriran pristop z uporabo drugih naravnih sovražnikov ščitkarja Aleurothrixus floccosus.

Ključne besede: citrus; biotično varstvo; populacijska dinamika; Aleurothrixus floccosus; Cales noacki; fenologija; Chlef; severozahodna Alžirija

\footnotetext{
1 University of Blida-1- Faculty of Nature and Life Sciences - Department of Biotechnology - Laboratory of Vegetables Biotechnologies Production., B.P. 270, road of Soumaa, Algeria, *corresponding author: a.mahmoudi@univ-chlef.dz

2 Mustafa Kemal University, Agriculture Faculty, Plant Protection Department, Antakya-Hatay, Turkey

${ }^{3}$ Office of Research \& Graduate Studies Alfaisal University Riyadh Saudi Arabia
} 


\section{INTRODUCTION}

Citrus (Citrus spp.) constitutes the major group of fruits including oranges, grapefruits, trifoliate orange, mandarins, pummelo, citranges and lemon (Gebreslasie \& Meresa, 2018). It serves as the main source of vitamins, mineral elements and sugar; hence, it controls the building process of the human body (Oviasogie et al., 2015). In Algeria, Chlef is the second most important citrus growing region with more than 5000 ha of which more than $90 \%$ old plantations (Bellabas, 2011).

Gebreslasie and Meresa, (2018) reported that a decline in productivity of citrus can be attributed to several factors including fungal, bacterial, viral, nematode, and insect pests.

Citrus trees are attacked by several insect pests including the woolly whitefly, Aleurothrixus floccosus (Maskell, 1896) and the citrus whitefly, Dialeurodes citri (Ashmead, 1885) causing considerable economic damage (Yigit \& Canhilal, 2005; Uygun \& Satar, 2008; Giliomee \& Millar, 2009; Tello Mercado et al., 2014; Abrol, 2015). The woolly whitefly was introduced accidentally in 1981 in western Algeria from Spain or Morocco (Doumandji \& Doumandji-Mitiche, 1986). Citrus woolly whitefly's populations are pervasive and cause infestations with serious damages to citrus sector (Biche, 2012; Mahmoudi et al., 2017). A. floccosus Maskell is characterized with wings covered by white waxy substance. The adult male is slightly smaller than female attaining about $1.5 \mathrm{~mm}$ (Tello Mercado et al., 2014). The woolly whitefly produces copious amounts of sticky honeydew from the lower surface of leaves of lemon and other Citrus species (Grout et al., 2012).

Chemical control of crop pests is known for the negative effects on human health and environment as well as having low efficacy against $A$. floccosus (Katsoyannos et al., 1997; Nega, 2011). This resistance against insecticide is due to the wool-like wax filaments which cover $3^{\text {rd }}$ and $4^{\text {th }}$ instar nymphs and pupae of $A$. floccosus impeding penetration of insecticides (Katsoyannos et al., 1997). Integrated management of fruit pests including biological control is crucial to the economic success of many regions in the world (Kissayi et al., 2017).

The parasitoid Cales noacki Howard, 1907, (Hymenoptera, Aphelinidae) is an effective natural enemy and biological control agent of this pest (; Grout et al., 2012; Telli \& Yiğit, 2012; Abrol, 2015).

There are few extensive reports which address the biological interaction of the woolly whitefly and its parasitoid C. noacki in the world (Ulusoy et al., 2003; ; Telli \& Yiğit, 2012; Tello Mercado et al., 2014; Kissayi et al., 2017; Gebreslasie and Meresa, 2018).

The objective of this work was to assess the effectiveness of the parasitoid biological control agent Cales noacki Howard (Hymenoptera, Aphelinidae) against the citrus pest woolly whitefly, Aleurothrixus floccosus Maskell in Northwestern Algeria. The infestation rates of orange trees by A. floccosus and the parasitism rates by $C$. noacki were investigated in order to determine the favorable conditions for population growth and reproduction of $A$. floccosus.

The relation between adults' emergence and the appearance of the growth flush (i.e. young shoots) was followed to explain the close relationship between the number of generations per year and the growth flush. In addition, the parasitism activity by C.noacki was evaluated.

\section{MATERIALS AND METHODS}

\subsection{Description of the case study area}

This study was conducted in an orchard, occupying 4 ha, belonging to the citrus growing region of Chlef $\left(36^{\circ} 05^{\prime} 53.3^{\prime \prime} \mathrm{N} 1^{\circ} 13^{\prime} 02.4^{\prime \prime} \mathrm{E}\right)$ situated in the northwest of Algeria (Figure 1). This area has a semi-arid bioclimatic stage with mild winters and dry periods extending from
mid-April to October's end. The 12-year-old orchard was planted with orange trees Citrus sinensis L. of the Thomson Navel variety. Orchard maintenance (pruning, manual weeding and fertilisation) were done at the right time without phytosanitary treatments. 


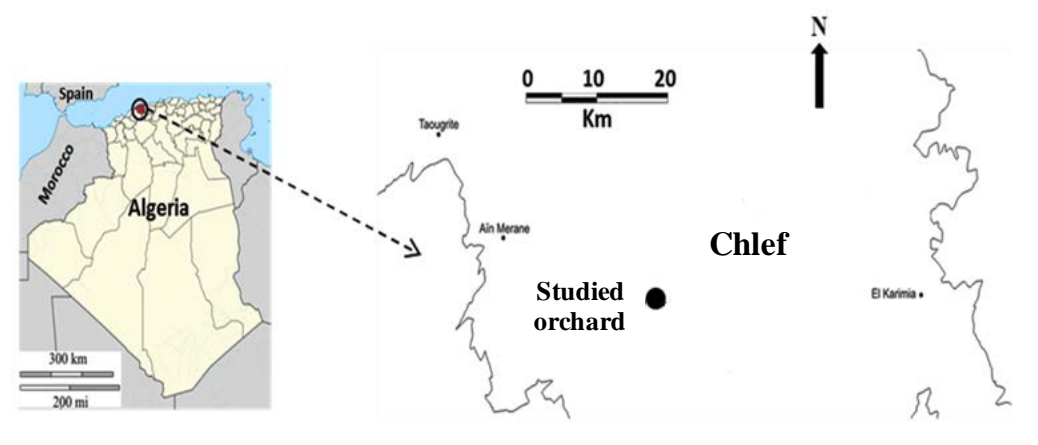

Figure 1: Geographical location of the case study orchard in the Chlef region of Northwestern Algeria

\subsection{Population sampling of $A$. floccosus}

The case study orchard was visited periodically each fortnight from July 2013 to June 2014. Ten whiteflyinfested trees were randomly sampled at each fortnight. Four branches on different orientations carrying young shoots and elderly leaves per tree were observed for the sampling of adults and live larvae. In a related study Telli \& Yiğit, (2012) considered the distribution of woolly whitefly on the four directions of citrus trees in Turkey.

Adult whiteflies as well as other circulating insects (i.e. entomofauna) within the orchard particularly the natural enemies of woolly whitefly, were caught through sticky traps. Three rectangular yellow plates Horiver-type (25 $\mathrm{x} 10 \mathrm{~cm}$ ) were deposited within the canopy at a height of $1.5 \mathrm{~m}$ at a rate of one trap per tree at a distance of 50 m (Ekbom \& Rumei, 1990). These traps were used to count the number of generations of several pests (Toorani \& Abbasipour, 2017). In addition, a total of 50 leaves were randomly collected in the plot at each survey to investigate larvae, pupae and parasitized larvae per $1 \mathrm{~cm}^{2}$.

\subsection{Infestation rates by $A$. floccosus}

The infestation rates of the global populations $(\mathrm{T})$ were calculated according to the Townsend-Heuberger formula (Townsend \& Heuberger, 1943) as follow:

$\mathrm{T}(\%)=[$ (number of branches with presence of whiteflies $\times$ corresponding presence index / sum of branches with presence $x 4) \times 100$ ]

The presence index was deduced from a scale of 0 to 4 and corresponds to intervals of abundance expressed as a percentage.

For the case of whiteflies:

(Index 1) $<25 \%$ of presence

(Index 2) $25-50 \%$ of presence

(Index 3) $50-75 \%$ of presence
(Index 4) $>75 \%$ of presence

\subsection{Parasitism Rates by C. noacki}

The parasitism rates were evaluated at each survey throughout the sampling period. Parasitized larvae were counted on a leaf area of $1 \mathrm{~cm}^{2}$ under binocular magnifying glass at $\times 40$ and the results were expressed in percent relatively to the total larvae on the observed surface.

The confirmation of the species of parasitoid emerged (C. noacki) was made from leaves carrying parasitized larvae collected and placed in rectangular boxes of dimensions $(15 \mathrm{~cm} \times 8 \mathrm{~cm} \times 5 \mathrm{~cm})$ containing cotton impregnated for emergence. Identification of the parasitoid was carried out using several identification keys (Doumandji \& Doumandji-Mitiche, 1986; Goulet \& Huber, 1993).

\subsection{Phenology of orange tree in relation to climatic data}

The periods of orange tree's growth flush during the study period were determined on the basis of the phenological growth stages described by Agusti et al. (1995). Meteorological data including rainfall amounts, average temperature values and relative humidity were obtained from the Boukadir meteorological station (5 $\mathrm{km}$ west of the orchard) belonging to the National Meteorological Office in Chlef.

\subsection{Statistical analysis}

The data were subjected to analysis of variance (ANOVA) for variable with normal distribution whereas the variables with abnormal distribution were subjected to the general linear model (G.L.M.). Differences at P < 0.05 were considered to be significant. The statistical analysis was accomplished using the computer software SPSS 16.0 for Windows (Chicago, IL, USA). 


\section{RESULTS}

\subsection{Fluctuations in abundance of $A$. floccosus}

3.1.1 Temporal variations in abundance indices of larval $\&$ adult populations of woolly whitefly

The results of temporal variations in abundance indices of larval and adult populations of $A$. floccosus on the branches of $C$. sinensis of the studied orchard are given in the Figure 2.

The evolution of adult abundance indices of A.floccosus according to the three growth flush $\left(1^{\text {st }} \mathrm{gf}, 2^{\text {nd }} \mathrm{gf}, 3^{\text {rd }} \mathrm{gf}\right)$, showed that the appearance of adults abundance peaks corresponding to the emergence of adults from pupae coincide with the appearance of young leaves of growth flush.

According to our survey, larvae index presents three significant abundance's peaks during the period of midNovember 2013, late February, and mid-June 2014 (Figure 2). In general, the analysis of fluctuations in adult abundance indices showed the existence of three peaks the most important among them was recorded in November 2013.

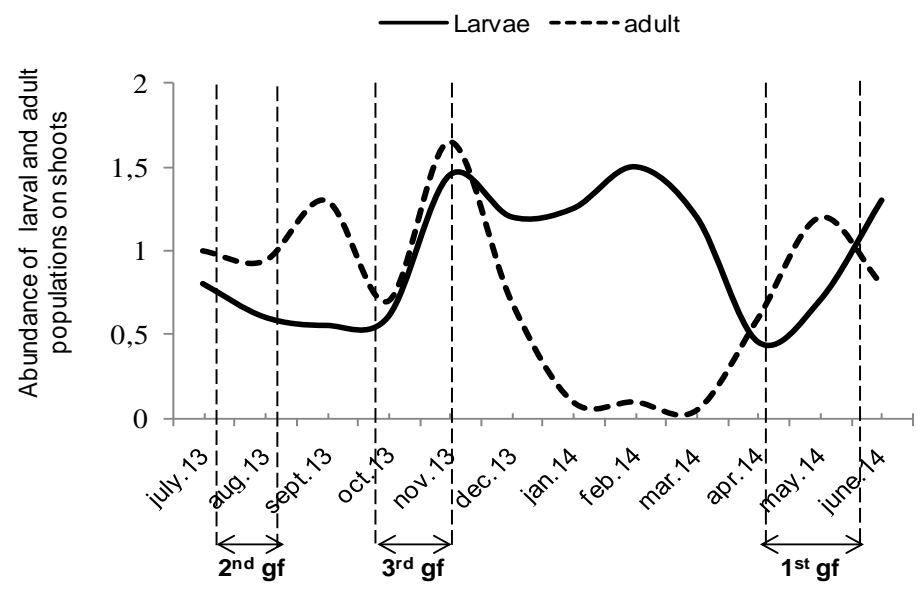

Figure 2: Temporal evolution of population abundance indices of $A$. floccosus on branches (gf: growth flush)

The evolution of adult A. floccosus caught through yellow traps revealed a stable distribution from July to late November, with a total ranging from 100 to 230 individuals per trap per month, except for midNovember attaining more than 275 individuals / trap / month.

In the last two months of the survey, a continuous evolution was observed in the adults recording about 600 adults / trap / month. The lowest enumeration of adults caught was recorded at end of March not exceeding 25 adults / traps / month (Figure 3). The first adults emerging from the pupae were noted in mid-June, end-October 2013 and early April 2014.

The analysis of the relationship between adult catches of woolly whitefly and orange's growth flush indicated that summer growth flush $\left(1^{\text {st }}\right.$ gf) and autumn growth flush $\left(3^{\text {rd }}\right.$ gf) coincided with the period of adult large trapping. 


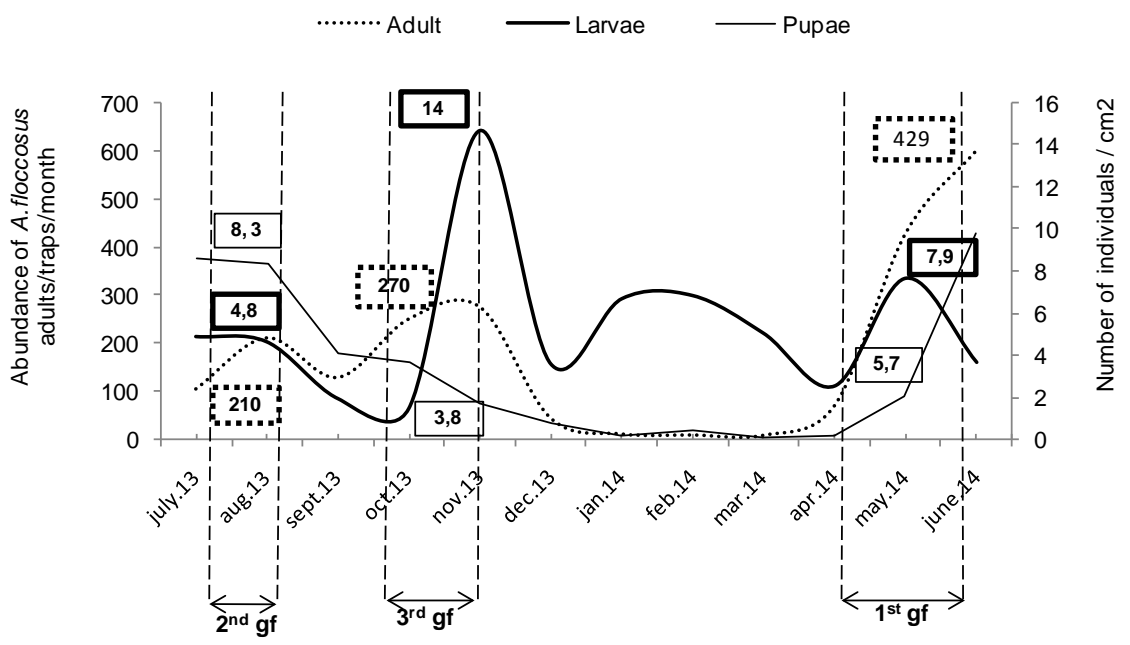

Figure 3: Evolution of the densities of the larval and pupal stages and adult catches by the sticky traps of the woolly whitefly. Absolute values shown in the graph represent abundance peaks of adults, larvae and pupae (gf: growth flush)

The evolution of $A$. floccosus biological stage was determined by counting the number of live larvae, pupariums on $1 \mathrm{~cm}^{2}$ in 50 leaves. The results are shown in Figure 3. As can be seen from this figure, the live larvae are present throughout the year at all stages of foliage. In contrast, the pupae were almost absent during the period ranging from November 2013 to April 2014.

Furthermore, in 2013, from July to October, the density of the pupae of woolly whitefly was higher than those of live larvae. From November (maximum density) to the end of April, only live larvae were present. The density of larvae exhibited its second peak at the end of May followed by a significant change in the number of nymphs (Figure 3).

\subsubsection{Variation in infestation rates of woolly whitefly}

The larvae of the whitefly infested the leaves throughout the sampling period. A first phase of infestation by A. floccosus larvae was characterized by rate infestation ranging between $19 \%$ to $39 \%$ from early July 2013 to Mid-January 2014.

A second phase with more abundant infestation was observed in mid-February with an infestation rate of more than $80 \%$, then it reduced gradually to remain at a rate of $20 \%$ during the month of April, a third stage of infestation was noted at the end of the sampling with a peak of more than $60 \%$ (Figure 4).

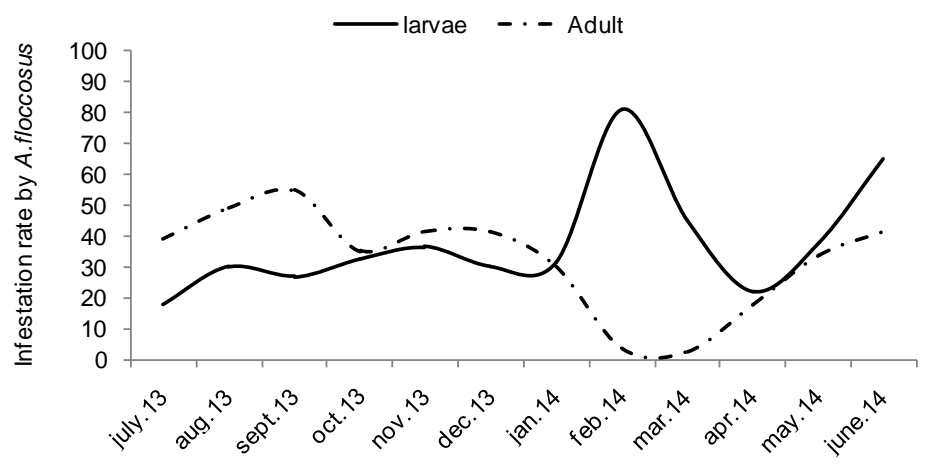

Figure 4: Temporal evolution of infestation rates of larvae and adults of $A$. floccosus on branches 
Adults infesting the canopy, has shown three phases of infestation, the first phase displayed the highest infestation rate, exceeding $65 \%$ in early September, coinciding with the $3^{\text {rd }}$ growth flush $\left(3^{\text {rd }} \mathrm{gf}\right)$ of 2013; the second period recorded low infestation rate from November to December and then decrease progressively to its lowest level from February to March; at the end of the sampling period, a rise in the infestation rate to a maximum of $40 \%$ was observed (Figure 4 ).

\subsubsection{Effect of exposure on spatiotemporal distribution of populations of $A$. floccosus}

The evolution of abundance fluctuations of adult populations on branches with young leaves showed a preference for exposure to layed eggs on the underside of young leaves.

Indeed, adults emerging during the three flight periods recorded through the sampling period exhibited a remarkable preference for the Northern exposure for setting in the deposition of eggs, the southern exposure was sought by adults during the $2^{\text {nd }}$ and $3^{\text {rd }}$ peaks as well as the $1^{\text {st }}$ peak with less importance (Figure 5).

On the other hand, it was noted that the larval distribution was not affected by either stage of leaves (old or young) not by their exposure during the sampling year (Figure 6).

The impact of different exposures/seasons on larval and adult distribution was analysed using ANOVA. The northern exposure of the canopy exhibited a significant effect on the distribution of adults on foliage comparatively to other exposures ( $p<0.05)$. Similarly, the distribution of $A$. floccosus adults appeared to be influenced by the follow-up period ( $<<0.05)$. However, the distributions of the larval populations seemed to be similar $(\mathrm{p}>0.05)$ on different exposures.
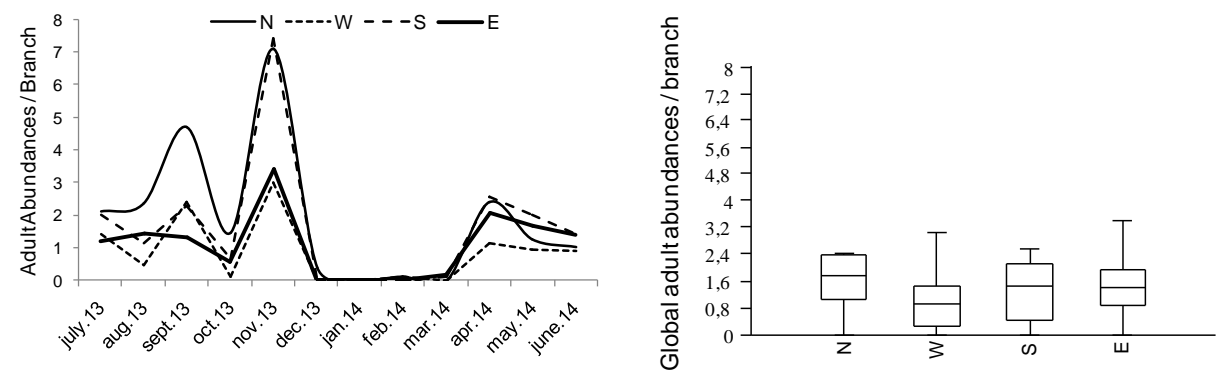

Figure 5: Effect of exposure on the distribution of adult populations (N: North, W: west, E: east, S: south)
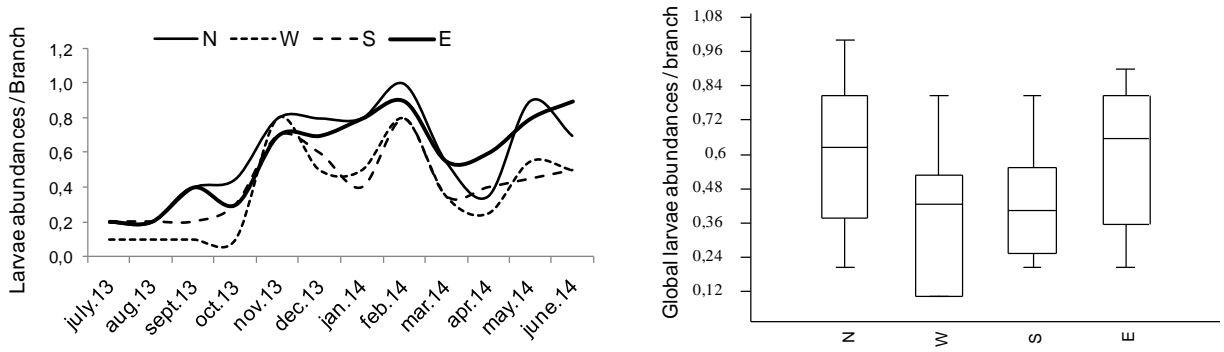

Figure 6: Effect of exposure on distribution of larval populations (N: North, W: west, E: east, S: south)

\subsubsection{Evolution of parasitism by C. noacki}

The temporal abundance and evolution of parasitism by $C$. noacki was followed during the sampling period. The results are presented in Figures 7.

As can be seen the parasitoid specific to A. floccosus, Cales noacki, showed three peaks of abundance, the most important was recorded at the end of sampling period during June 2014 with 16 individuals / trap / month (Figure 7). Nevertheless, for the rest of sampling period, few parasitoid adults were caught, not exceeding two individuals / trap / month. 
Figure 7 shows $C$. noacki's parasitism activity recorded throughout the sampling period, the highest activity was registered in July 2013 with more than $75 \%$ of parasitism. This rate decreased gradually to a stable interval between $5 \%$ and $30 \%$ during the other months of the year. This rate of parasitism is calculated according to the number of parasitized larvae in relation to the total number of larvae per $\mathrm{cm}^{2}$.

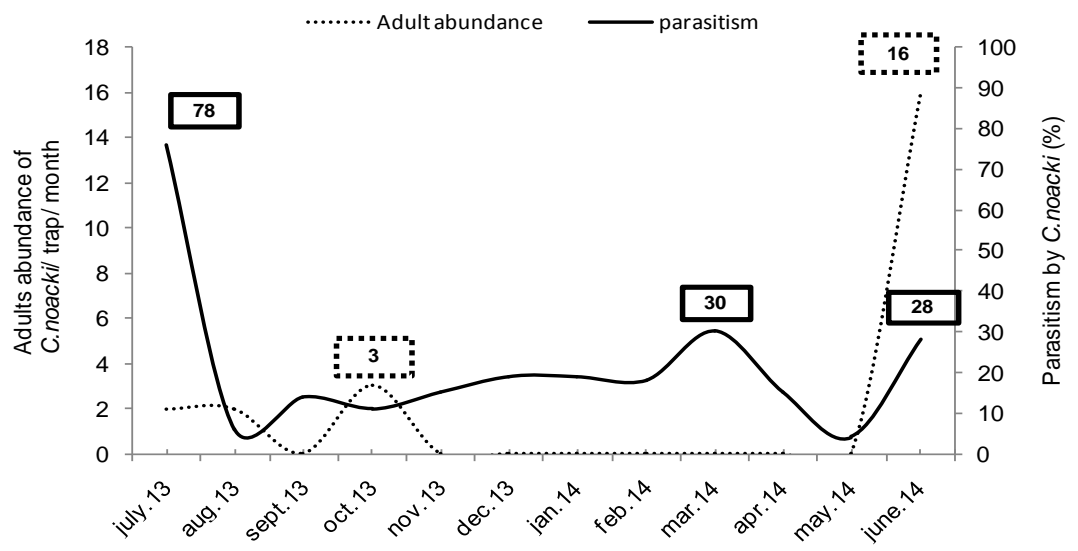

Figure 7 : Evolution of parasitism rate by $C$. noacki emerged from A. floccosus \& adult catches in traps on orange trees

\section{DISCUSSION}

Ulusoy et al., (2003) reported that the woolly whitefly does not have a preference for specific citrus varieties. However, it has been observed mainly on orange trees in the Mediterranean region (Barbagallo et al., 1986) where considerable damage for citriculture has been reported especially in Italy (Del-Bene \& Gargani, 1991).

Furthermore, there are numerous studies on the population dynamics of Aleurothrixus floccosus (Onillon, 1973; Gebreslasie \& Meresa, 2018).

In Algeria, few studies on this species have been carried out (Doumandji-Mitiche \& Doumandji, 1988; Berkani, 1989). The current study has shown that there are three generations during a one year period. In contrast, Biche (2012) estimated that the woolly whitefly evolves in four to five generations per year, almost uninterrupted throughout the year with a simple slowdown noted during the colder months. The slowdown in infestation rates of larvae and adults of $A$. floccosus during the colder Algerian months of January to April was also noted in the present investigation (Figure 4).

Depending on the phonological characteristics of the Citrus (i.e. persistence of foliage, rhythmicity of appearance of growth flush), the dynamics of the pest populations are influenced by the host plant because of the qualitative and quantitative evolution of the resources offered (Bran \& Onillon, 1978; Kissayi et al.,
2017). This species spends the winter at the third or fourth instar larvae and sometimes at the egg stage, laid in the autumn by the last generation of adults.

Additionally, under the specific climatic conditions of the citrus region of Chlef, it has been noted that the first spring generation appears with the young shoots of the first growth flush of orange trees as a result of the first laying of the year. Ripa et al., (1999) and Giliomee \& Millar, (2009) estimated that the underside of young leaves is preferred by the whitefly to feed and oviposit.

In another study, Onillon (1973) reported, that in early spring, the adults of the woolly whitefly prefer the young bitter-orange tree shoots resulting from a total transfer of the imaginal population on leaves of the first growth flush. These results are consistent with those cited by Abbassi (1980).

A second summer generation was recorded in the months of August coinciding with the 2nd summer growth flush. The latest generation and the largest in adults' number started with the new leaf outputs of the latest growth flush. However, Katsoyannos et al., (1997) have counted six overlapping generations in Athens. Grout et al., (2012), estimate that new infestations of $A$. floccosus are, habitually, associated with growth flushes. 
The period from January to March corresponds to the hibernation period of the woolly whitefly in the current case study region where there was sometimes a total absence of adults; the lower faces of leaves were observed to be encrusted by larvae and exuviae, covered with sooty mould.

These findings were in accordance with those mentioned by Onillon (1973) and supported by the reports of Gebreslasie and Meresa, (2018).

The difference in the number of generations of A.floccosus between the region of Mitidja where it evolves in four to five generations (Doumandji-Mitiche \& Doumandji, (1988); Biche, 2012) and the region of Chlef (three generations) can be explained by the specific climatic conditions of the Chlef province.

Indeed, the mean of minimum temperatures of the case study Chlef region varied between $12-20{ }^{\circ} \mathrm{C}$ and the maximum oscillating between $25-33{ }^{\circ} \mathrm{C}$ which was shown as favorable for the emergence of adults to trigger egg laying on the lower side of young leaves.

In support of this, France et al., (2011) estimated that the favorable average temperature for the development and reproduction of $A$. floccosus varies between $10.8^{\circ} \mathrm{C}$ and $28.5{ }^{\circ} \mathrm{C}$ in northern Chile which is in the same range as observed in the current study.

The present results suggest that the rainfall pattern does not affect the whitefly population dynamics. The ideal moisture levels coinciding with the flight periods of adults varied between $50 \%$ and $75 \%$.

Furthermore the yellow sticky traps can be considered as an effective tool for monitoring the population dynamics of crop pests, especially whiteflies (Prema et al., 2018). Adults caught by yellow traps accurately reflects the flight periods of woolly whitefly. The flight peaks effectively correspond to the generations of $A$. floccosus. In a related study, Prema et al., (2018) used different colored sticky traps including blue, white, yellow, red and green to monitor the movement of thrips (i.e. sucking pests similar to whiteflies) and the number of thrips catches at different growth stages of cotton growth. Results of their field trials confirmed that yellow sticky traps attracted more thrips compared to other colors.

In the existing study, in summer the number of adults caught reached more than 600 individuals per trap/month, in contrast to what was observed in situ where the autumn period was characterized by a large number of emerged adults.
This result could be due to the fact that the yellow sticky traps enable the capture of adults natives in the case study orchard as well as of the entomofauna circulating at the level of the orchards close to the study station.

The live larvae enumerated on $1 \mathrm{~cm}^{2}$ of foliage showed that the latter occurred on the lower side of the leaves throughout the year, which explains the large number of adults caught by the traps or counted in the foliage.

The rate of parasitism by $C$. noacki was very high at $78 \%$ during the month of July. In contrast this rate did not exceed $30 \%$ during the other sampling periods. Katsoyannos et al., (1998), consider that in Greece, $C$. noacki is an effective natural enemy against woolly whitefly with parasitism rates exceeding $82 \%$.

In another report, Telli \& Yiğit, (2012) estimated that rates of parasitism by $C$. noacki in Turkey ranged from $70 \%$ to $88 \%$. Similarly, rates of parasitism reaching $90 \%$ on clementine trees and $75 \%$ on orange trees were reported by Doumandji and Doumandji-Mitiche (1986) for the Mitidja region in Algeria.

In a related study, a survey of Aphelinidae (Hymenoptera: Chalcidoidea) species associated with crop and forest pests in Morocco was conducted by Kissayi et al., (2017). The authors concluded that the knowledge of Aphelinidae especially in North Africa countries is still incomplete. They also argued that further study is required to implementing biological control of crop pests and taxonomic studies of parasitic wasps for sustainable agriculture in countries of the North Africa region.

The spatiotemporal distribution of the adults depends of climatic conditions, the phenology of the orange tree (growth flush) and exposure or orientation of the leaf. It has been demonstrated that the north and south exposure are the most populated by the adults of the woolly whitefly; this can be explained by the presence of a large number of young leaves favoring the laying and the installation of A. floccosus (Onillon, 1973; Meagher, 2008).

Additionally, the evolution of the curve of the larvae parasitized by $C$. noacki showed that the parasitism activity is very intense during the summer and spring period and is remarkably low during the winter period, which may be due to unfavorable climatic conditions. The decline in the rates of parasitism in the present work observed between November and the beginning of May can be explained by the influence of the wind shear at $3.9-4.4 \mathrm{~m} \mathrm{~s}^{-1}$ which was able to involuntary unhooking off the endoparasitic larvae, as they are fixed less firmly on the plant than those that are healthy. 
Whereas, Ulusoy et al. (2003) found that the decline in parasitism may be due to the effect of frost, which destroyed parasitized larvae that lack the cottony mass that protects live healthy larvae.

In Algeria, several releases of the parasitoid C. noacki were carried out in 1985 and 1986, by Doumandji and Doumandji-Mitiche (1986). The parasitoid was able to settle in Mitidja and was able to limit the outbreak of $A$. floccosus. The presence of this parasitoid in the Chlef region can be explained by the adaptability of $C$. noacki which can makes it an effective tool for biological regulation against the woolly whitefly.
A similar case study of the insect pest complex of citrus, their natural enemies and their management at Keren in Eritrea has been reported by Husain et al., (2017). Furthermore, Gebreslasie and Meresa, (2018) noted that many pests can attack citrus. This suggests that an integrated approach may be needed in the protection of citrus orchards in Algeria. While Husain et al., (2017) focused primarily on chemical control; this may not be the best way forward due to environmental concerns. Integrated biological control of citrus pests using various parasitoids is recommended.

\section{CONCLUSIONS}

The present study was the first detailed characterization of the relationship between woolly whitefly $A$. floccosus, the parasitoid $C$. noacki and the appearance of new citrus shoots in orange trees ('Thomson Navel') in the Chlef Northwestern Algerian region. The wooly whitefly pest prefers young shoots to settle and lay eggs.

Results showed remarkable variations in abundance indices and infestation rates of larvae and adults that depended on the growth flush in foliage and meteorological conditions of the region. The woolly whitefly manifested three flight periods coinciding with three growth flushes of orange sap; in autumn towards the end of September followed by mid-November with the highest average abundance of 10 individuals per branch and a third flight period in mid-May.
Phases of growth flush seemed to have an effect on the temporal distribution of adults over the sampling period from July to June. Pest emergence appeared favorable at $12-20{ }^{\circ} \mathrm{C}$ as the minimum interval temperature whereas the maximum varied between $25-33{ }^{\circ} \mathrm{C}$ with humidity levels of $50 \%$ and $75 \%$. In the current case study region, as for the incidence of $C$. noacki on the wooly whitefly, their impact was not optimum due to the large fluctuations in number of whiteflies. Although the pestparasitoid complex appears to be important in the orchard, the biological regulation exerted by $C$. noacki is insufficient for the complete neutralization of $A$. floccosus. An integrated approach is needed using additional natural enemies associated with the woolly whitefly.

\section{REFERENCES}

Abbassi, M. (1980). Études relatives à Aleurothrixus floccosus Maskell et à son parasite spécifique Cales noacki Howard. Les cahiers de la recherche agronomique, 35, 77-157.

Abrol, D. P. (2015). Pollination Biology, Vol.1: Pests and pollinators of fruit crops. Switzerland. Springer International PublishingAgusti, M., Zaragoza, S., Bleiholder, H., Buhr, L., Hack, H., klose, R., Stauss, R. (1995). Escala BBCH para la descripción de los estadios fenológicos del desarrollo de los agrios (Gén. Citrus). Levante Agricola Revista internacional de citricos, (3),189-199.

Barbagallo, S., Longo, S., Rapisarda, C. (1986). Whiteflies and psyllid injurious to citrus. In Integrated Pest Control in Citrus Groves. In Proceedlings Experts Meeting , (pp. 89-98). Acireale
Bellabas, A. (2011). Etude de Base sur les agrumes en Algérie. Ed1, Food and Agriculture Organization, 5-7.

Berkani, A, (1989). Possibilités de régulation des populations d'Aleurothrixus floccosus Mask. (Homopt., Aleurodidae) sur agrumes par Cales noacki How. (Hymenopt., Aphelinidae) en Algérie. Thèse de Doctorat Etat. Université Aix-Marseille, France.

Biche, M. (2012). Les principaux insectes ravageurs des agrumes en Algérie et leurs ennemis naturels. Guide pratique, 4-5.

Bran, P., Onillon, J.C. (1978). Dynamique du végétal et estimation des populations de ravageurs inféodés aux Citrus. Fruits, 33, 807-810.

Del-Bene, G., Gargani E. (1991). Osservazioni su Aleurothrixus floccosus (Mask.) (Hom.: Aleyrodidae) e sul suo antagonista Cales noacki

Acta agriculturae Slovenica, 111 - 2, september 2018 
How. (Hym. Aphelinidae) in Toscana. Redia, 74 (1),11-126.

Doumandji, S., Doumandji-Mitiche, B. (1986). Introduction de Cales noaki (Hym., Aphelinidae) en Mitidja pour lutter contre Aleurothricxus floccosus (Hom., Aleyrodidae). Annales de l'institut national agronomique ElHarrach, 10 (2), $44-46$.

Doumandji-Mitiche, B. \& Doumandji, S.E. (1988). Note sur l'instalation en Metidja de Cales noacki HOW. (Hym. Aphelinidae) ennemi naturel de l'aleurode floconneux Aleurothrixus floccosus MASK (Hom. Aleurodidae)., INA, 12, 66-88.

Ekbom, B.S., Rumei, X. (1990). Sampling and spatial patterns of whiteflies. In: Whiteflies: their Bionomics, Pest Status and Management. (D. Gerling, ed.). Intercept Ltd, Andover, 107-121.

France, A., Gerding, M., Tello, V., Peralta, O., Sepúlveda, M. (2011). Investigation about Adaptability of Entomopathogenic Fungi in Pica. INIA Quilamapu, Universidad Arturo Prat, Iquique.

Gebreslasie, A., \& Meresa, H. (2018). Identification of insect and disease associated to citrus in Northern Ethiopia. African Journal of Microbiology Research, 12(13), 312-320. doi:10.5897/AJMR2017.8780

Giliomee, J.H., Millar, I.M. (2009). The woolly whitefly, Aleurothrixus floccosus (Maskell) (Hemiptera: Aleyrodidae), a potentially serious citrus pest, recorded from South Africa. African Entomology, 17(2),

232-233. doi:10.4001/003.017.0216

Goulet, H., \& Huber J.T, (1993). Hymenoptera of the world: An identification guide to families. Ottawa, Ontario, Centre for Land and Biological Resources Research.

Grout, T.G., Kirkman, W., Moore, S.D. (2012). Woolly whitefly, Aleurothrixus floccosus, on citrus in South Africa. Citrus Research International, South Africa. Fruit Journal, 79-81.

Hussain, M. A., Ahmad, T., Tekeste, M., Teklemariam, N., Abraham, N., \& Mehari, N. (2017). A case study of insect pest complex of citrus and their management at Keren, Eritrea, and a note on their natural enemies. Journal of Entomology and Zoology Studies, 5(3), 1226-1230.

Katsoyannos, P., Ifantis, K., Kontodimas, D.C. (1997). Phenology, population trend and natural enemies of Aleurothrixus floccosus (Hom.: Aleyrodidae) at a newly invadedarea in Athens, Greece. Entomophaga, 42, 619-628. doi:10.1007/BF02769820
Katsoyannos, P., Kontodimas, D.C., Stathas, G.J. (1998). The inundative release of Cales noacki Howard (Hymenoptera: Aphelinidae), for curative treatment of Aleurothrixus floccosus (Maskell) (Homoptera: Aleyrodidae) on heavily infested citrus in Greece. Annals of the Benaki Phytopathological Institute, 18, 111-122.

Kissayi, K., Benhalima, S., \& Smaili, M. C. (2017). New records of Aphelinidae (Hymenoptera: Chalcidoidea) from Morocco and comparison with North Africa region fauna. Journal of Entomology and Nematology, 9(7), 55-62.

Mahmoudi, A., Allal Benfekih, L., Rouabhi, A. (2017). Approche fonctionnelle de la diversité des communautés d'insectes auxiliaires dans un verger de clémentinierà Chlef. Revue Agrobiologia, 7(2), 445-458.

Meagher, R, (2008). Citrus Pests and their Management. In Encyclopedia of Entomology, (pp. 878-903). Netherlands, Springer.

Nega, A. (2011). Integrated management of woolly whitefly [Aleurothrixus floccusus (maskell) homoptera: aleyrodidae] on citrus at adama, east shewa zone, ethiopia. Thesis Haramaya University.

Onillon, J.C. (1973). Contribution à l'étude de la dynamique des populations d'homoptères inféodés aux agrumes.V.2. Possibilités de régulation des populations d'Aleurothrixus floccosus Mask. (Homoptera, Aleurodidae) sur agrumes par Cales noacki HOW(Hymenoptera, Aphelinidae). Bulletin OEPP/EPPO , 3 (1), 17-26.

Oviasogie, F.E., Ogofure, A.G., Beshiru, A., Ode, J.N., Omeje, F.I. (2015). Assessment of fungal pathogens associated with orange spoilage. African journal of Microbiology Research, 9 (29), 17581763. doi:10.5897/AJMR2014.7246

Prema, M.S., Ganapathy, N., Renukadevi, P., Mohankumar, S., Kennedy, J.S. (2018). Coloured sticky traps to monitor thrips population in cotton. Journal of Entomology and Zoology Studies, 6(2), 948-952.

Ripa, R., Rodríguez, F., Rojas, S., Larral, P., Castro, L., Ortúzar, J., Carmona, P., Vargas, R. (1999). Citrus Pests, their Natural Enemies and Management. INIA Books Collection.

Telli, Ö., Yiğit A. (2012). Hatay ili turunçgillerinde zararlı Turunçgil pamuklu beyazsineği, Aleurothrixus floccosus (Maskell) ve Turunçgil ipek beyazsineği, Paraleyrodes minei Iaccarino (Hemiptera: Aleyrodidae) 'nin doğal düşmanları. Türkiye Entomoloji Dergisi, 36 (1), 147-154. 
Tello Mercado, V., Fernández, E.S., Giliomee, J.H. (2014). Life table parameters of the woolly whitefly Aleurothrixus floccosus (Hemiptera: Aleyrodidae) and its parasitoid Cales noacki (Hymenoptera: Aphelinidae). European Journal of Entomology, 111 (2), 251-256. doi:10.14411/eje.2014.020

Toorani, A H., Abbasipour, H. (2017). Effect of geographical directions, height and the color of yellow traps in capture of Mediterranean fruit fly, Ceratitis capitata (Wiedemann, 1824) in citrus orchards. Acta agriculturae Slovenica, 109 (3), 561-575. doi:10.14720/aas.2017.109.3.08

Townsend, G.K. \& Heuberger, J.W., (1943). Methods for estimating losses caused by diseases in fungicide experiments. Plant Disease Reporter, 27 (17), 340-343.

Ulusoy, M.R., Vatansever, G., Erkılıc, L., Uygun, N. (2003). Studies on Aleurothrixus floccosus
(Maskell) (Homoptera, Aleyrodidae) and its parasitoid, Cales noacki Howard (Hymenoptera, Aphelinidae) in the East Mediterranean Region of Turkey. Journal of Pest Science, 76,163-169. doi:10.1007/s10340-003-0014-5

Uygun N., Satar S. (2008). The Current Situation of Citrus Pest and Their Control Methods in Turkey. Integrated Control in Citrus Fruit Crops, IOBC/wprs Bulletin, 38, 2-9.

Yigit, A., Canhilal, R. (2005). Establishment and dispersal of Serangium parcesetosum Sicard (Coleoptera, Coccinellidae), a predatory beetle of citrus whitefly, Dialeurodes citri Ashm (Homoptera, Aleyrodidae) in the East Mediterranean region of Turkey. Journal of Plant Diseases and Protection, 112 (3), 268-275. 